\title{
Identification of anticholinergic activity of drugs of the Brazilian National List of Essential Drugs
}

\author{
Mariana Sampaio LIMA ${ }^{1}$, Adriano Max REIS ${ }^{2}$ \\ ${ }^{1}$ Secretaria Municipal de Saúde de Mariana, Mariana, Minas Gerais; ${ }^{2}$ Faculdade de Farmácia da Universidade Federal de Minas Gerais \\ Corresponding author: Lima MS, marianasrlima31@gmail.com
}

Submitted: 26-12-2018 Resubmitted: 08-01-2019 Accepted: 17-04-2020

Peer review: blind reviewer and Marco Túlio Cintra

\begin{abstract}
Objectives: Identify drugs from the National List of Essential Medicines-Rename 2018 that have anticholinergic activity and scales of anticholinergic activity available for use in clinical practice. Methods: Drug utilization study, emphasizing the analysis of supply. The drugs included in Brazilian National List of Essential Drugs (BNLED) 2018 were classified according to level 3 of the chemical therapeutic anatomical classification. A literature review was performed to identify anticholinergic activity measurement scales. Anticholinergic activity of BNLED 2018 drugs was determined using the Composite anticholinergic scale. Results: It was identified two systematic reviews, among the 13 identified scales, Duran's Scale and Composite Anticholinergic Scale. Composite Anticholinergic Scale is the most comprehensive with 197 drugs. It was found that $14.6 \%$ of the drugs have anticholinergic activity and $69.1 \%$ are included in the basic component of the national list. Drugs with central nervous system activity constitute about $50 \%$ of the substances with anticholinergic activity, mainly comprised of antipsychotics, followed by cardiovascular system drugs, mostly represented by betablockers. The cumulative effect of anticholinergic activities, from several drugs prescribed concomitantly, reflects the importance of verifying prescriptions and aware health professionals of strategies to reduce this impact. Conclusions: To measure anticholinergic load in clinical practice, 13 scales are available. The most comprehensive scale is the Composite Anticholinergic Scale. Although medicines with anticholinergic activity are uncommon among medicines included in BNLED 2018, it is needed to provide information to prescribers due to the negative clinical outcomes attributed to cumulative anticholinergic burden.
\end{abstract}

Keywords: cholinergic antagonist, drugs, essential, aged, pharmaceutical services.

\section{Identificação da atividade anticolinérgica dos medicamentos da Relação Nacional de Medicamentos Essenciais}

\section{Resumo}

Objetivo: Identificar os medicamentos da Relação Nacional de Medicamentos Essenciais-Rename 2018 que possuem atividade anticolinérgica e as escalas de atividade anticolinérgica disponíveis para uso na prática clínica Métodos: Estudo de utilização de medicamentos, tipo análise da oferta. Classificou-se os medicamentos da Rename 2018 segundo o nível 3 da classificação anatômica terapêutica química. Realizou -se revisão da literatura para identificação das escalas de mensuração da atividade anticolinérgica. Determinou-se atividade anticolinérgica dos medicamentos da Rename 2018, empregando a Composite Anticholinergic Scale. Resultados: Entre as 13 escalas identificadas, a Duran's Scale e a Composite anticholinergic scale foram elaborados por meio de revisão sistemática. A Composite anticholinergic scale é a mais abrangente com 197 fármacos. Verificou-se que, 14,6\% dos fármacos possuíam atividade anticolinérgica, 69,1\% desses estão compreendidos no componente básico da assistência farmacêutica. Dos fármacos que possuem atividade anticolinérgica, cerca de $50 \%$ referem-se a fármacos de ação no sistema nervoso central, compreendendo principalmente os antipsicóticos, seguidos pelos fármacos do sistema cardiovascular, que representados em sua maioria pelos betabloqueadores. Conclusão: Para mensuração da carga anticolinérgica na prática clínica estão disponíveis 13 escalas. A escala a com maior abrangência de fármacos é a Composite Anticholinergic Scale. Apesar dos medicamentos com atividade anticolinérgica serem pouco frequentes entre os medicamentos incluídos na Rename 2018, é necessário disponibilizar informações aos prescritores devido os desfechos clínicos negativos atribuídos a carga anticolinérgica acumulativa.

Palavras-chave: antagonistas colinérgicos, medicamentos essenciais, idoso, assistência farmacêutica. 


\section{Introduction}

Drugs that have intrinsic anticholinergic properties work by blocking the acetylcholine receptors in the central and peripheral nervous system ${ }^{1-4}$, and are considered classic anticholinergics, such as atropine and oxybutynin $n^{5-6}$. However, there are drugs that have indirect anticholinergic activity and are not related to their primary indication, such as antidepressants and antipsychotics ${ }^{6}$ The use of anticholinergic drugs can cause adverse effects on the peripheral (tachycardia, flushing, urinary retention, hyperthermia, blurred vision, and constipation) and central (cognitive worsening, attention deficit, confusion, and delirium) cholinergic systems ${ }^{3,4}$

Medications with intrinsic or indirect anticholinergic activity are used to treat chronic and acute health conditions and are included in the pharmacotherapy of most older adults ${ }^{6}$. The use of these drugs in the older adult population is a special concern, due to the physiological changes related to age $\mathrm{e}^{7,8}$. Peripheral pharmacokinetic changes may cause decreased hepatic and renal clearance, raising the drug levels in the plasma and contributing to the occurrence of adverse anticholinergic events. ${ }^{7}$. There are also central pharmacokinetic changes, which possibly influence anticholinergic sensitivity, such as increased blood-brain barrier permeability and P-glycoprotein dysfunction, which can facilitate access of the drug to the central nervous system ${ }^{9}$.

The use of multiple drugs with anticholinergic activity determines a cumulative anticholinergic burden ${ }^{3,10}$. The effects of exposure to anticholinergics are consequences of the accumulation of actions from different drugs and not just of exposure to a single drug with high anticholinergic properties ${ }^{10}$. A significant portion of the anticholinergic burden in the prescriptions of the older adults is related to low anticholinergic drugs ${ }^{11,12}$. An elevated anticholinergic burden is associated with unfavorable clinical outcomes in the older adults, with an increased chance of developing cognitive impairment, and with deficits in executive function, memory, and processing speed ${ }^{13-15}$. In addition, it contributes to weakness, fatigue, cognitive and psychomotor deceleration, and falls ${ }^{16,17}$.

Many drugs prescribed for the older adults are not routinely recognized as having anticholinergic activity and, thus, the risk of cumulative anticholinergic burden is neglected ${ }^{17}$. However, there is still no standard for measuring anticholinergic burden. Recently, several attempts have been made to produce reliable lists to measure anticholinergic burden and, consequently, the potential to produce adverse effects ${ }^{5}$. These scales serve as a tool to assist in the clinical practice and it is increasingly important to systematize information about the anticholinergic burden of drugs ${ }^{17}$.

The National List of Essential Medicines (Rename) is a guiding instrument for the professional clinical practice in Brazil, contributing to the standardization of prescriptions. In addition, it is a guiding element of medication logistic actions within the scope of the Public Health System and a basis for the organization of state and municipal lists ${ }^{18}$. It is known that a considerable portion of the Brazilian population has free access to medications for the treatment of chronic non-communicable diseases, through public health strategies ${ }^{19}$. This access to medicines considered essential is provided for by the National Medicines Policy (Política Nacional de Medicamentos, $\mathrm{PNM})^{18}$. Therefore, this study aims to identify Rename 2018 drugs with anticholinergic activity and also the scales of anticholinergic activity available for use in the clinical practice.

\section{Methods}

A drug utilization study, of the supply analysis type, which allows knowing the quality and information about the medicines available for use in the clinical practice ${ }^{20}$.

A literature review was carried out in order to use the most robust scale and that best assessed the correlation of exposure to anticholinergic activity and the effects on the individuals. The PubMed/Medline databases were consulted, with no defined period, using the Medical Subject Headings (MeSH) terms and descriptors: (cholinergic antagonists OR anticholinergic OR nicotinic antagonists OR muscarinic antagonists) AND (scale OR load OR burden OR exposure) AND aged. The search was then limited to the English language. The articles were selected by title and abstract. Studies were included which presented a list of scores or classification of drugs regarding their anticholinergic activity. Studies that evaluated only one pharmacological class or which used a weak methodology to evaluate information available in package inserts were excluded.

Medicines from the three components of pharmaceutical assistance: basic, strategic and specialized, listed in Rename 2018 were included in the analysis. Medications in topical, otological, and inhalation pharmaceutical forms were excluded, due to the irrelevance of the systemic effects of these formulations. The drugs were classified regarding their anticholinergic activity, according to the criteria established in the article selected in the previous stage. Then, the percentage of drugs with anticholinergic burden was determined considering the total of drugs listed in Rename 2018. The drugs were classified according to Level 3 of the Anatomical Therapeutic Chemical (ATC) Classification System. The data were recorded in an Exce $^{\circledR}$ spreadsheet and the statistical analysis included determinations of frequency and proportions.

\section{Results}

The database search captured 1,353 articles. Reading the title and abstract allowed selecting 19 articles for full reading. In the reading process of the 19 selected articles, six were excluded because they did not meet the inclusion and exclusion criteria. Therefore, 13 scales of classification of anticholinergic activity were identified; their methodologies and number of drugs listed were summarized in Table 1.

The methodology used in the elaboration of the scales is diversified, including determination of serum anticholinergic activity, affinity with the muscarinic receptor, expert opinion, and previous studies and scales. The Anticholinergic Drug Scale ${ }^{10}$, Clinician-Rated Anticholinergic Score ${ }^{23}$, Anticholinergic Risk Scale $^{30}$, Anticholinergic Cognitive Burden Scale ${ }^{4}$, Anticholinergic Activity Scale ${ }^{25}$, Anticholinergic Load Scale ${ }^{26}$, Muscarinic Acetylcholinergic Receptor Antagonist Exposure ${ }^{27}$, Anticholinergic Effect on Cognition ${ }^{29}$, and the Anticholinergic Impregnation Scale ${ }^{28}$, are based on previous studies/scales and expert opinions. In addition, the Anticholinergic Activity Scale ${ }^{25}$, Anticholinergic Load Scale ${ }^{26}$ and Anticholinergic Impregnation Scale ${ }^{28}$ instruments were also based on trials of serum anticholinergic activity. The Anticholinergic Effect on Cognition ${ }^{29}$ scale also verified the affinity with muscarinic receptors for each drug found. Two systematic reviews were identified that drew up a new classification list for anticholinergic activity: the Duran's Scale ${ }^{5}$ and the Composite Anticholinergic Scale (CAS) ${ }^{21}$. 
Table 1. Characteristics of the studies for the elaboration of the scales for measuring anticholinergic activity.

\begin{tabular}{|c|c|c|c|c|c|}
\hline Study & Anticholinergic scale & Participants & Method & $\begin{array}{l}\text { №. of listed } \\
\text { medications }\end{array}$ & $\begin{array}{l}\text { Classification } \\
\text { System }\end{array}$ \\
\hline $\begin{array}{l}\text { Carnahan et al., } 2006 \\
\left(\text { USA) }{ }^{10}\right.\end{array}$ & $\begin{array}{l}\text { Anticholinergic Drug Scale } \\
\text { (ADS) }\end{array}$ & $\begin{array}{l}\text { Older adults living in a } \\
\text { long-term institution }\end{array}$ & $\begin{array}{l}\text { Based on previously pub- } \\
\text { lished scales and on expert } \\
\text { opinions }\end{array}$ & 117 & Score 0-3 \\
\hline $\begin{array}{l}\text { Ancelin et al., } 2006 \\
\text { (France) } 22\end{array}$ & $\begin{array}{l}\text { Anticholinergic Burden } \\
\text { Classification ( } A B C)\end{array}$ & $\begin{array}{l}\text { Individuals > } 60 \text { years old } \\
\text { without dementia }\end{array}$ & $\begin{array}{l}\text { Based on serum } \\
\text { anticholinergic activity } \\
\text { determined through } \\
\text { published studies with } \\
\text { radio-receptor and through } \\
\text { expert opinions }\end{array}$ & 27 & Score 0-3 \\
\hline 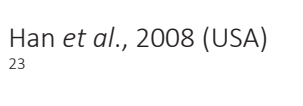 & $\begin{array}{l}\text { Clinician-Rated } \\
\text { Anticholinergic Score } \\
\text { (CRAS) }\end{array}$ & $\begin{array}{l}\text { Men with hypertension > } \\
65 \text { years old }\end{array}$ & $\begin{array}{l}\text { Based on a previously } \\
\text { published scale and on } \\
\text { expert opinions }\end{array}$ & 60 & Score 0-3 \\
\hline $\begin{array}{l}\text { Rudolph et al., } 2008 \\
\text { (USA) }\end{array}$ & $\begin{array}{l}\text { Anticholinergic Risk Scale } \\
\text { (ARS) }\end{array}$ & $\begin{array}{l}\text { Men } \geq 65 \text { years old in } \\
\text { geriatric clinics and } \\
\text { primary care }\end{array}$ & $\begin{array}{l}\text { Based on literature review } \\
\text { and on expert opinions }\end{array}$ & 49 & Score 0-3 \\
\hline Chew et al., (USA) ${ }^{24}$ & $\begin{array}{l}\text { Serum Anticholinergic } \\
\text { Activity (SAA) }\end{array}$ & - & $\begin{array}{l}\text { Based on a trial with radio- } \\
\text { receptors }\end{array}$ & 107 & $\begin{array}{l}\text { Score } 0,0 /+,+,++ \\
+++\end{array}$ \\
\hline $\begin{array}{l}\text { Boustani et al., } 2008 \\
\text { (USA) }^{4}\end{array}$ & $\begin{array}{l}\text { Anticholinergic Cognitive } \\
\text { Burden (ACB) Scale }\end{array}$ & - & $\begin{array}{l}\text { Based on systematic review } \\
\text { and on expert opinions }\end{array}$ & 88 & Score 1-3 \\
\hline $\begin{array}{l}\text { Ehrt et al., } 2010 \\
\text { (Norway) }^{25}\end{array}$ & $\begin{array}{l}\text { Anticholinergic Activity } \\
\text { Scale (AAS) }\end{array}$ & $\begin{array}{l}\text { Patients diagnosed with } \\
\text { Parkinson's Disease }\end{array}$ & $\begin{array}{l}\text { Based on the study by } \\
\text { Chew et al., } 2008 \text { and on } \\
\text { expert opinions }\end{array}$ & 99 & Score 0-4 \\
\hline $\begin{array}{l}\text { Sittironnarit et al., } 2011 \\
\text { (Australia) }^{26}\end{array}$ & $\begin{array}{l}\text { Anticholinergic Load (ACL) } \\
\text { Scale }\end{array}$ & $\begin{array}{l}\text { Individuals > } 60 \text { years old. } \\
\text { Three groups: healthy } \\
\text { individuals, with mild } \\
\text { cognitive impairment and } \\
\text { Alzheimer's disease }\end{array}$ & $\begin{array}{l}\text { Based on previously } \\
\text { published scales and on } \\
\text { expert opinions }\end{array}$ & 49 & Score 0-3 \\
\hline $\begin{array}{l}\text { Duran et al., } 2013 \\
\text { (Ecuador) }^{5}\end{array}$ & Duran's Scale (DS) & - & $\begin{array}{l}\text { Systematic review of } \\
\text { previous scales }\end{array}$ & 100 & $0-2$ \\
\hline $\begin{array}{l}\text { Salahudeen et al., } 2015 \\
\text { (New Zeeland) }^{21}\end{array}$ & $\begin{array}{l}\text { Composite Anticholinergic } \\
\text { Scale (CAS) }\end{array}$ & - & $\begin{array}{l}\text { Systematic review of } \\
\text { previous scales }\end{array}$ & 197 & $\begin{array}{l}\text { Cholinergic load } \\
\text { classified into: Low, } \\
\text { Moderate, and High. }\end{array}$ \\
\hline $\begin{array}{l}\text { Klamer et al., } 2016 \\
\text { (Belgium) }\end{array}$ & $\begin{array}{l}\text { Muscarinic } \\
\text { Acetylcholinergic Receptor } \\
\text { ANTagonist Exposure } \\
\text { (MARANTE) }\end{array}$ & - & $\begin{array}{l}\text { Based on the Duran's } \\
\text { List drugs, on authorized } \\
\text { sources and on expert } \\
\text { opinions }\end{array}$ & 41 & $\begin{array}{l}\text { Potency } 0-2 \text { and } \\
\text { dosage }(0 ; 0.5 ; 1 ; \\
1.5 ; 2)\end{array}$ \\
\hline $\begin{array}{l}\text { Bishara et al., } 2017 \\
\text { (United Kingdom) }^{29}\end{array}$ & $\begin{array}{l}\text { Anticholinergic Effect on } \\
\text { Cognition (AEC) }\end{array}$ & - & $\begin{array}{l}\text { Based on literature review } \\
\text { and on expert opinions }\end{array}$ & 122 & $\begin{array}{l}\text { Score } 0-3 \text { (or unable } \\
\text { to classify) }\end{array}$ \\
\hline $\begin{array}{l}\text { Briet et al., } 2017 \\
\text { (France) }^{28}\end{array}$ & $\begin{array}{l}\text { Anticholinergic Impregna- } \\
\text { tion Scale (AIS) }\end{array}$ & $\begin{array}{l}\text { Patients from a psychiat- } \\
\text { ric clinic }\end{array}$ & $\begin{array}{l}\text { Based on previously pub- } \\
\text { lished scales and on expert } \\
\text { opinions }\end{array}$ & 128 & Score 1-3 \\
\hline
\end{tabular}

The scale proposed by Salahudeen and collaborators ${ }^{21}$ was based on a systematic review of scales of anticholinergic activity, seven studies were used to elaborate the classification of drugs. 197 drugs were listed, therefore being the most comprehensive. In addition, the clinical impacts of the use of the selected anticholinergic drugs were verified through studies that show an association between exposure to anticholinergic drugs and cognitive and functional adverse effects. For these attributes, the $\mathrm{CAS}^{21}$ scale was selected for the identification and classification of drugs with anticholinergic activity included in Rename 2018. Therefore, they were classified as low, moderate, and high anticholinergic activity. Of the 375 drugs from Rename 2018, 55 (14.6\%) have anticholinergic activity as described in Table 2. It was identified that $38(69.1 \%)$ of the drugs with anticholinergic activity are of the basic component of pharmaceutical assistance, $3(5.4 \%)$ are of the strategic component, and 17 (30.9\%) are of the specialized component. It is worth mentioning that clindamycin hydrochloride and prednisone are included in the basic and strategic components. Approximately $50 \%$ of the drugs with anticholinergic activity listed in Rename 2018 are from Group N of the ATC, drugs that act on the nervous system, especially antipsychotics, dopaminergic agents, and antidepressants, followed by Group C drugs: drugs acting on the cardiovascular system (18\%), and from Group A: alimentary tract and metabolism (7.2\%).

According to the CAS scale, 42 (76.4\%) of the drugs have low anticholinergic activity, 5 (9.1\%) have medium anticholinergic activity, and 8 (14.5\%) have high anticholinergic activity (Table 3 ).

\section{Discussion}

The literature review on scales for measuring anticholinergic burden demonstrated heterogeneity of methodologies used in the studies, covering trials of serum anticholinergic activity with radio-receptors, in vitro measure of affinity for muscarinic receptors, and lists developed by a panel of experts. The systematic reviews identified made an analysis of the studies with the different methodologies, the two reviews found were based on seven studies and differed in only one study; both highlight the 
Table 2. Description of the Rename 2018 Drugs with anticholinergic activity according to the CAS ${ }^{21}$ scale and to the ATC classification.

\begin{tabular}{|c|c|c|}
\hline ATC classification & Medicine & $\begin{array}{c}\text { Number of } \\
\text { medications (\%) }\end{array}$ \\
\hline \multicolumn{3}{|l|}{ Group A - Alimentary tract and metabolism } \\
\hline A10B - Oral medication for reducing blood glucose & Metformin hydrochloride & \multirow{4}{*}{$4(7.2)$} \\
\hline A02B - Medication for peptic ulcer and gastroesophageal reflux & Ranitidine Hydrochloride & \\
\hline A03B - Belladonna derivatives & Atropine sulfate & \\
\hline A03F - Propulsive medications & Metoclopramide hydrochloride & \\
\hline \multicolumn{3}{|l|}{ Group B - Blood and hematopoietic organs } \\
\hline B01A - Antithrombotic agents & Warfarin & $1(1.8)$ \\
\hline \multicolumn{3}{|l|}{ Group C - Cardiovascular system } \\
\hline C01A - Cardiac glycosides & Digoxin & \\
\hline C01D - Vasodilators used in heart disease & Isosorbide dinitrate, Isosorbide mononitrate & \\
\hline CO2D - Drugs that act on arteriolar smooth muscles & Hydralazine & \\
\hline C03C - Loop diuretics & Furosemide & $10(18.0)$ \\
\hline C07A - Beta blockers & Atenolol, Metoprolol succinate, Metoprolol tartrate & \\
\hline C08C - Selective calcium channel blocker & Nifedipin & \\
\hline C09A - Angiotensin-converting enzyme inhibitors & Captopril & \\
\hline \multicolumn{3}{|l|}{ Group H - Systemic hormones } \\
\hline H02A - Corticosteroids for systemic use & $\begin{array}{l}\text { Dexamethasone, Prednisolone Sodium phosphate, } \\
\text { Methylprednisolone, Prednisone, Hydrocortisone sodium } \\
\text { succinate }\end{array}$ & $5(9.0)$ \\
\hline \multicolumn{3}{|l|}{ Group J - Systemic anti-infectives } \\
\hline J01F - Macrolides and Lincosamides & Clindamycin hydrochloride & $1(1.8)$ \\
\hline \multicolumn{3}{|l|}{ Group L - Antineoplastics and immuno-modulators } \\
\hline L04A - Immuno-suppressants & Azathioprine, Cyclosporine, Methotrexate & $3(5.4)$ \\
\hline \multicolumn{3}{|l|}{ Group N - Nervous system } \\
\hline N02A - Opioids & Methadone hydrochloride, Codeine phosphate, Morphine sulfate & \\
\hline N03A - Antiepileptics & Valproic acid, Carbamazepine, Clonazepam, Phenobarbital & \\
\hline N04B - Dopaminergic agents & $\begin{array}{l}\text { Amantadine hydrochloride, Selegiline hydrochloride, Pramipexole } \\
\text { dihydrochloride, Entacapone, Levodopa + Carbidopa*, } \\
\text { Bromocriptine mesylate }\end{array}$ & \\
\hline N05A - Antipsychotics & $\begin{array}{l}\text { Lithium carbonate, Chlorpromazine hydrochloride, Ziprasidone } \\
\text { hydrochloride, Clozapine, Haloperidol/Haloperidol decanoate, } \\
\text { Quetiapine hemifumarate, Olanzapine, Risperidone }\end{array}$ & $28(50.6)$ \\
\hline N05B - Anxiolytics & Diazepam & \\
\hline N05C - Hypnotics and sedatives & Midazolam & \\
\hline N06A - Antidepressants & $\begin{array}{l}\text { Amitriptyline hydrochloride, Bupropion hydrochloride, } \\
\text { Clomipramine hydrochloride, Fluoxetine hydrochloride, } \\
\text { Nortriptyline hydrochloride }\end{array}$ & \\
\hline \multicolumn{3}{|l|}{ Group R - Respiratory system } \\
\hline R06A - Antihistamines for systemic use & Promethazine hydrochloride, Loratadine, Dexclopheniramine & $3(5.4)$ \\
\hline
\end{tabular}

discrepancies in the scores attributed to the drugs in the different scales. Salahudeen and collaborators ${ }^{21}$ listed a greater number of drugs and compiled studies with different methodologies, which allowed for the analysis of the association between the use of drugs with anticholinergic activity and cognitive and functional outcomes, risk of hospitalization, and mortality. The use of different methods in the elaboration allows comparing the data obtained in different studies with the production of a more robust scale, since it becomes possible to associate the individual's exposure to the drugs with anticholinergic activity and the occurrence of peripheral and central adverse effects.

The results of the Rename 2018 analysis showed that the proportion of drugs with anticholinergic activity in Rename is small. Most of the drugs identified have low anticholinergic activity and are mostly included in the basic component of pharmaceutical assistance. The basic component drugs are mainly used for the treatment of prevalent and priority problems in primary care and, consequently, the population's access to these drugs is more common. In the context of the ongoing demographic and epidemiological transition in the country, chronic noncommunicable diseases that require pharmacological treatment for prolonged periods become evident, and the older adults stand out for presenting multimorbidity and for being one of the main users of medications ${ }^{31,32}$.

Most Rename drugs identified with anticholinergic activity belong to Group N, drugs with action on the nervous system. A populationbased study on the use of psychiatric drugs by older adults in the community identified that benzodiapines and antidepressants were the most used therapeutic classes. It was also verified that the medical diagnosis report for depression was the factor most strongly associated with the use of psychiatric drugs. ${ }^{33}$ The National Survey on Access, Use and Promotion of the Rational Use of Medications (Pesquisa Nacional sobre Acesso, Utilização e Promoção do Uso Racional de Medicamentos, PNAUM) in 
Table 3. Description of the scores of the anticholinergic activity of the drugs included in Rename 2018, according to the pharmaceutica assistance component.

\begin{tabular}{|c|c|c|c|c|c|c|c|}
\hline \multirow{2}{*}{ Medicine } & \multicolumn{3}{|c|}{ Component } & \multirow{2}{*}{ Medicine } & \multicolumn{3}{|c|}{ Component } \\
\hline & Basic & Strategic & Special & & Basic & Strategic & Special \\
\hline Valproic acid (sodium valproate) & 1 & - & - & Digoxin & 1 & - & - \\
\hline Atenolol & 1 & - & - & Isosorbide dinitrate & 1 & - & - \\
\hline Azathioprine & - & - & 1 & Entacapone & - & - & 1 \\
\hline Captopril & 1 & - & - & Phenobarbital & 1 & - & - \\
\hline Carbamazepine & 2 & - & - & Codeine phosphate & - & - & 1 \\
\hline Lithium carbonate & 1 & - & - & Prednisolone sodium phosphate & 1 & - & - \\
\hline Cyclosporine & - & - & 1 & Furosemide & 1 & - & - \\
\hline Clonazepam & 1 & - & - & Haloperidol/Haloperidol decanoate & 2 & - & - \\
\hline Amantadine hydrochloride & - & - & 2 & Quetiapine hemifumarate & - & - & 1 \\
\hline Amitriptyline hydrochloride & 3 & - & - & Levodopa + carbidopa & 1 & - & - \\
\hline Bupropion hydrochloride & - & 1 & - & Loratadine & 1 & - & - \\
\hline Clindamycin hydrochloride & 1 & 1 & - & Dexchlorpheniramine maleate & 3 & - & - \\
\hline Clomipramine hydrochloride & 3 & - & - & Bromocriptine mesylate & - & - & 1 \\
\hline Chlorpromazine hydrochloride & 3 & - & - & Methylprednisolone & - & - & 1 \\
\hline Fluoxetine hydrochloride & 1 & - & - & Methotrexate & - & - & 1 \\
\hline Hydralazine hydrochloride & 1 & - & - & Midazolam & 1 & - & - \\
\hline Methadone hydrochloride & - & - & 2 & Isosorbide mononitrate & 1 & - & - \\
\hline Metformin hydrochloride & 1 & - & - & Nifedipin & 1 & - & - \\
\hline Metoclopramide hydrochloride & 1 & - & - & Olanzapine & - & - & 2 \\
\hline Nortriptyline hydrochloride & 3 & - & - & Prednisone & 1 & 1 & - \\
\hline Promethazine hydrochloride & 3 & - & - & Risperidone & - & - & 1 \\
\hline Ranitidine hydrochloride & 1 & - & - & Metoprolol succinate & 1 & - & - \\
\hline Selegiline hydrochloride & - & - & 1 & Hydrocortisone sodium succinate & 1 & - & - \\
\hline Ziprasidone hydrochloride & - & - & 1 & Atropine sulfate & 3 & - & - \\
\hline Clozapine & - & - & 3 & Morphine sulfate & - & - & 1 \\
\hline Dexamethasone & 1 & - & - & Metoprolol tartrate & 1 & - & - \\
\hline Diazepam & 1 & - & - & Warfarin & 1 & - & - \\
\hline Pramipexole dihydrochloride & - & - & 1 & & & & \\
\hline
\end{tabular}

Classification of anticholinergic activity according to the CAS scale ${ }^{21}$ : 1- Low anticholinergic activity 2- Medium anticholinergic activity 3- High anticholinergic activity

Brazil demonstrated that the drugs most used by individuals with depression were fluoxetine, clonazepam, and amitriptyline. ${ }^{34}$ Benzodiazepines and tricyclic antidepressants are considered potentially inadequate drugs for the older adults due to their profile of adverse effect ${ }^{15}$. That is, with regard to the safety of the drug therapy, the treatment instituted in the elderly population has not been the most adequate. There are safer therapeutic alternatives for this population; however, they are not available in the public network. In addition, other drugs frequently used by this population are risperidone, haloperidol, and lithium carbonate ${ }^{34}$. These findings alert to the need to think about the therapeutic specificities of the older adults in future Rename reviews.

It is known that there is an increased risk of adverse drug reactions, provided by the physiological changes of aging, making this population particularly vulnerable to the cognitive effects ${ }^{7}$. This occurs both due to anticholinergic sensitivity and to the easy access of the drug to the central nervous system ${ }^{7,9}$. A number of studies have already consistently shown that changes or abnormalities in the choline transporter, acetylcholine release, and expression of muscarinic and nicotinic receptors are associated with cognitive and peripheral effects ${ }^{4}$.

In this sense, the cumulative anticholinergic burden from drugs gains importance in the context of polypharmacy. A PNAUM showed that, of the total older adults, $18.0 \%$ used at least five medications and that this polypharmacy was higher among the oldest individual ${ }^{32}$.
In assessing the comorbidities, the prevalence of polypharmacy was $60.0 \%$ among those who reported at least four diseases ${ }^{32}$. Older adults on polypharmacy use drugs from different pharmacological classes, including anticholinergic drugs that have a direct anticholinergic effect. In addition, drugs from other pharmacological groups, such as antidepressants and antipsychotics, have indirect anticholinergic activity and are not related to their therapeutic indication ${ }^{6}$. It is known that the cumulative effect of several drugs with low anticholinergic activity is more common in the older adults than the use of drugs with high activity. An assessment of the prescription of anticholinergic medications for older adults in primary care in Australia identified that $70 \%$ of the anticholinergic burden in the older adults assessed was determined by the use of medications with low anticholinergic activity ${ }^{11,35}$. In this study, it was noticed that the drugs with high and moderate anticholinergic activity are mostly drugs that act on the nervous system. These drugs are mainly available through the basic and specialized component.

A significant proportion of prescribers do not recognize the indirect anticholinergic activity of drugs that have this property, as well as the adverse effects of anticholinergic drugs ${ }^{36}$. In addition, changes in pharmacokinetics and pharmacodynamics resulting from senescence and senility must be considered when making decisions about the drugs to be prescribed. This reinforces the importance of providing information on the anticholinergic activity of the drugs, especially the basic components where drugs with low 
anticholinergic activity predominate. In view of this, it is relevant to encourage the development of a scale that includes information on the drugs available in Brazil that have anticholinergic activity, far beyond those included in Rename 2018. Accurate, up-to-date, and independent information about medications qualifies the prescription process, especially with regard to specificities for the older adults. It is worth mentioning the role of the pharmacist in working together with the geriatrician to qualify this prescription process and to provide safer clinical practices for the older adults.

The publication of National Therapeutic Forms ${ }^{37}$ is recommended to provide information on medications in national health systems. Since 2008, Brazil has systematized the National Therapeutic Form with information on Rename's medications for the purpose of guiding prescribers and health professionals, contributing to the rational use of medications. The current edition, published in 2010, does not present with the necessary emphasis the anticholinergic activity of drugs, especially for those with indirect activity. It is known that the scales for measuring anticholinergic activity are heterogeneous in relation to the drugs included and that they do not fully cover all the medications with this activity. The systematization of this information for health professionals is of great value. Thus, it is suggested that these aspects be included in the drug monographs, in the National Therapeutic Form, and that the impact due to these effects be addressed in the chapter on medications in the older adults.

The knowledge of the intensity of anticholinergic activity helps in decision making and is used to calculate the total anticholinergic burden, which is based on the sum of the anticholinergic burdens assigned to each medication in use. For this, it is necessary to carry out the pharmacological anamnesis to identify all the drugs in use and then assess the anticholinergic burden of each one, using the scales in the literature. The calculation must consider the specific score of each scale. Finally, anticholinergic burdens must be added; this will be the total anticholinergic burden. A value equal to or above 3 for the total anticholinergic burden is considered clinically relevant, being necessary to assess the risk-benefit ratio of the discontinuation or replacement of the medications ${ }^{35}$. The MARANTE scale considers the maintenance dose of the drugs in use; the total anticholinergic burden considered clinically relevant is equal to or greater than 2 points ${ }^{27}$.

Considering the clinical impact of the accumulation of anticholinergic burden from drugs in older adults, it is necessary to make prescribers and other health professionals aware of the strategies to reduce this impact. Some strategies can be adopted, such as using drugs with anticholinergic activity for the shortest possible treatment time; in case of chronic treatment, choosing therapeutic alternatives with less anticholinergic activity or alternatives that, in different aspects, are more suitable for the older adults to treat the health condition in question.

One of the limitations of this study is that the literature search is restricted to Pubmed/Medline. However, as a comprehensive search was carried out, without date restrictions, it was possible to identify a greater number of scales.

Despite this limitation, the study provides data for health managers, contributing to improving the quality of health care and the management of pharmaceutical care. Another strength of the research is that it contributes with elements that can subsidize actions to promote the safe use of medications, in particular directed to the older adults, whose harmful impact of the exposure to anticholinergic medications on the functionality presents scientific evidence.

\section{Conclusion}

13 scales for measuring anticholinergic activity were identified for use in the clinical practice. Medications with anticholinergic activity are uncommon among those included in Rename. The therapeutic class of the ATC system with the highest frequency of drugs with anticholinergic activity is Group N, the nervous system, with emphasis on antipsychotics. It is necessary to increase the availability of information on drugs with anticholinergic activity, especially in the National Therapeutic Form, in order to provide safer clinical practices to the older adults. Still, it is of great value that more studies be carried out to verify the anticholinergic activity of the most used drugs in Brazil.

\section{Funding sources}

This research did not receive any funding.

\section{Collaborators}

Lima MS and Reis AM conceived the project. Lima MS collected the data and wrote the article. Lima MS and Reis AM participated in the analysis and interpretation of the data and carried out a critical review of the article. All authors approved the version to be published and assumed responsibility for all information on the work, ensuring the accuracy and integrity of any part of the work.

\section{Acknowledgments}

To all the participants who collaborated with this study.

\section{Conflict of interest statement}

The authors declare that there are no conflicts of interest regarding this article.

\section{References}

1. Mesulam, MM. The cholinergic innervation of the human cerebral cortex. Progress in Brain Research. 2004;145: 67-78.

2. Barak S. Modeling cholinergic aspects of schizophrenia: focus on the antimuscarinic syndrome. Behavioural Brain Research. 2009; 204.2: 335-351.

3. Gerretsen P, Pollock BG. Cognitive risks of anticholinergics in the elderly. Aging Health. 2013; 9(2): 159-166.

4. Boustani M., Campbell N., Munger S, et al. Impact of anticholinergics on the aging brain: a review and practical application. Aging Heath. 2008; 4(3): 311-320.

5. Durán CE, Azermai M, Vander Stichele RH. Systematic review of anticholinergic risk scales in older adults. European Journal of Clinical Pharmacology. 2013; 69(7): 1485-1496.

6. Nishtala PS, Salahudeen MS, Hilmer SN. Anticholinergics: theoretical and clinical overview. Expert Opinion on Drug Safety. 2016;15(6): 753-768.

7. Leon C, Gerretsen P, Uchida H, et al. Sensitivity to antipsychotic drugs in older adults. Current Psychiatry Reports. 2010;12(1): 28-33. 
8. Schliebs R, Arendt T. The cholinergic system in aging and neuronal degeneration. Behavioural Brain Research. 2011; 221(2): 555-563.

9. Brenner S S, Klotz U. P-glycoprotein function in the elderly. European Journal of Clinical Pharmacology. 2004; 60(2): $97-$ 102.

10. Carnahan RM, Lund BC, Perry PJ, et al. The anticholinergic drug scale as a measure of drug-related anticholinergic burden: associations with serum anticholinergic activity. The Journal of Clinical Pharmacology, 2006; 46(12): 1481-1486.

11. Mate KE, Kerr KP, Williams E, et al. Impact of multiple lowlevel anticholinergic medications on anticholinergic load of community-dwelling elderly with and without dementia. Drugs \& Aging. 2015; 32(2): 159-167.

12. Lu C, Tune LE. Chronic exposure to anticholinergic medications adversely affects the course of Alzheimer disease. The American Journal of Geriatric Psychiatry. 2003; 11(4): 458461.

13. Cancelli I, Gigli GL, Piani A. et al. Drugs with anticholinergic properties as a risk factor for cognitive impairment in elderly people: a population-based study. Journal of Clinical Psychopharmacology. 2008; 28(6): 654-659.

14. Carrière I, Fourrier-Reglat A, Dartigues J-F, et al. Drugs with anticholinergic properties, cognitive decline, and dementia in an elderly general population: the 3-city study. Archives of Internal Medicine. 2009;169(14): 1317-1324.

15. Aizenberg D, Sigler M, Weizman A, et al. Anticholinergic burden and the risk of falls among elderly psychiatric inpatients: a 4-year case-control study. International Psychogeriatrics. 2002; 14(3): 307-310.

16. Nebes RD, Pollock B, Halligan EM, et al. Serum anticholinergic activity and motor performance in elderly persons. The Journals of Gerontology Series A: Biological Sciences and Medical Sciences. 2007;62(1): 83-85.

17. Kersten H, Wyller TB. Anticholinergic drug burden in older people's brain-how well is it measured? Basic \& clinical pharmacology \& toxicology. 2014;114(2): 151-159.

18. Brasil. Ministério da Saúde, Secretaria de Ciência, Tecnologia e Insumos Estratégicos, Departamento de Assistência Farmacêutica e Insumos Estratégicos. Relação Nacional de Medicamentos Essenciais: RENAME 2018. Brasília: Ministério da Saúde, 2018. 218 p.

19. Tavares NUL, Luiza VL, Oliveira MA, et al. Acesso gratuito a medicamentos para tratamento de doenças crônicas no Brasil. Revista de Saúde Pública. 2016;50(2): 1s-10s.

20. Osorio-de-Castro CGS, Mosegui GBG, Peixoto MAP, et al. Estudos de utilização de medicamentos: noções básicas, 20å Ed. Rio de Janeiro, Fiocruz, 2000: 27-47p.

21. Salahudeen MS, Duffull SB, Nishtala PS. Anticholinergic burden quantified by anticholinergic risk scales and adverse outcomes in older people: a systematic review. BMC geriatrics. 2015; 15(1): 3 .

22. Ancelin ML, ArteroS, Portet F. Non-degenerative mild cognitive impairment in elderly people and use of anticholinergic drugs: longitudinal cohort study. BMJ. 2006; 332(7539): 455-459.
23. Han L, Agostini JV, Allore HG. Cumulative anticholinergic exposure is associated with poor memory and executive function in older men. Journal of the American Geriatrics Society. 2008; 56(12): 2203-2210.

24. Chew ML, Musant BH, Pollock BG, et al. Anticholinergic activity of 107 medications commonly used by older adults. Journal of the American Geriatrics Society. 2008; 56(7): 1333-1341.

25. Ehrt U, Broick K, Larsen JP, et al. Use of drugs with anticholinergic effect and impact on cognition in Parkinson's disease: a cohort study. Journal of Neurology, Neurosurgery \& Psychiatry. 2010; 81(2): 160-165.

26. Sittironnarit $\mathrm{G}, \mathrm{Ames} \mathrm{D}$, Bush Al, et al. Effects of anticholinergic drugs on cognitive function in older Australians: results from the AIBL study. Dementia and geriatric cognitive disorders. 2011;31(3): 173-178.

27. Klamer TT, Wauters $M$, Azermai $M$, et al. A novel scale linking potency and dosage to estimate anticholinergic exposure in older adults: the muscarinic acetylcholinergic receptor ANTagonist exposure scale. Basic \& clinical pharmacology \& toxicology. 2017; 120(6): 582-590.

28. Briet J, Javelot $H$, Heitzmann $E$, et al. The anticholinergic impregnation scale: Towards the elaboration of a scale adapted to prescriptions in French psychiatric settings. Therapie. 2017; 72(4): 427-437.

29. Bishara D, Harwood D, Sauer J, et al. Anticholinergic effect on cognition (AEC) of drugs commonly used in older people. International Journal of Geriatric Psychiatry. 2017; 32(6): 650-656.

30. Rudolph JL, Salow MJ, Angelini MC, et al. The anticholinergic risk scale and anticholinergic adverse effects in older persons. Archives of Internal Medicine .2008, 168(5): 508-513.

31. Pereira KG, Peres MA, IOP D, et al. Polifarmácia em idosos: um estudo de base populacional. Revista Brasileira de Epidemiologia. 2017;20: 335-344

32. Ramos LR, Tavares NUL, Bertoldi AD, et al. Polifarmácia e polimorbidade em idosos no Brasil: um desafio em saúde pública. Rev. Saúde Pública. 2016;50(2).

33. Abi-Ackel MM, Lima-Costa MF, Castro-Costa E, et al. Uso de psicofármacos entre idosos residentes em comunidade: prevalência e fatores associados. Revista Brasileira de Epidemiologia. 2017, 20: 57-69.

34. Brasil. Ministério da Saúde. Secretaria de Ciência, Tecnologia e Insumos Estratégicos. Componente populacional: resultados. Brasília; 2016. (Série PNAUM - Pesquisa Nacional sobre Acesso, Utilização e Promoção do Uso Racional de Medicamentos no Brasil; Caderno 3), p. 30.

35. Moraes EM. A arte da (des)prescrição no idoso: a dualidade terapêutica, 1ํeed. Belo Horizonte. Editora Folium, 2018; 266-305.

36. Araklitis G, Thiagamoorthy G, Hunter J, et al Anticholinergic prescription: are healthcare professionals the real burden? International Urogynecology Journal. 2017; 28(8): 1249-1256.

37. Brasil. Departamento De Assistência Farmacêutica e Insumos Estratégicos Formulário Terapêutico Nacional 2010, 2ed. 2011 Brasília: Ministério da Saúde: 2011, 1135p 